\title{
Hubungan Dukungan Keluarga dengan Kepatuhan ODHA yang Menjalani Terapi Pengobatan Antiretroviral (ARV) di Klinik VCT Puskesmas Jumpandang Baru Kota Makassar
}

\author{
Junaiddin $^{1 *}$ \\ 1*. STIKES Papua, Jl. Kanal Victory Km.10, Kota Sorong, Indonesia, 98416 \\ *e-mail: junaiddin92@gmail.com
}

(Received: 25-11-2019.; Reviewed: 09-12-2019; Accepted: 28-12-2019)

\begin{abstract}
ODHA (People with HIV / AIDS) is a term for someone who has HIV / AIDS. HIV stands for Human Immunodeficiency Virus, a type of virus that attacks the human immune system. AIDS stands for Acquired Immuno Deficiency Syndrome, which is a collection of symptoms of a disease (syndrome) obtained due to a decrease in immunity caused by HIV. The purpose of this study is to determine the relationship of family support undergoing antiretroviral (ARV) treatment at the VCT Clinic, Puskesmas Jumpandang Baru, Makassar City. The population in this study were all patients who come to the VCT Clinic, Jumpandang Baru Health Center, Makassar City. In October there were 313 people. Sampling by means of consecutive sampling using a large sample formula that can be as many as 40 respondents. Data collection using questionnaire sheets. Data that has been collected, processed and analyzed using Microsoft Excel computer programs and statistical programs (SPSS) version 16.0. The results of univariate analysis by looking for frequency distribution and bivariate analysis with the Alternative Fisher's Exact Test $(p<0.05)$ to determine the relationship between variables. Based on the results of statistical tests there is a relationship between family support ( $p=0.003,<\alpha=0.05)$, Ha is accepted. There is a significant relationship between family support and ODHA compliance undergoing antiretroviral (ARV) treatment at the VCT Clinic, Jumpandang Baru Health Center, Makassar City. Conclusion there is a relationship of family support with ODHA adherence undergoing antiretroviral (ARV) treatment at the VCT Clinic, Puskesmas Jumpandang Baru, Makassar.
\end{abstract}

Keywords: Family Support, Therapy Compliance, ODHA

\begin{abstract}
Abstrak
ODHA (Orang Dengan HIV/AIDS) adalah sebutan untuk seseorang yang telah mengidap HIV/AIDS. HIV singkatan dari Human Immunodeficiency Virus yaitu sejenis virus yang menyerang sistem kekebalan tubuh manusia. AIDS singkatan dari Acquired Immuno Deficiency Syndrom, yaitu kumpulan gejala penyakit (sindrom) yang didapat akibat turunnya kekebalan tubuh yang disebabkan oleh HIV. Tujuan penelitian untuk mengetahui hubungan dukungan keluarga yang menjalani pengobatan antiretroviral (ARV) di Klinik VCT Puskesmas Jumpandang Baru Kota Makassar. Populasi dalam penelitian ini adalah semua pasien yang datang di Klinik VCT Puskesmas Jumpandang Baru Kota Makassar, pada bulan Oktober sebanyak 313 orang. Pengambilan sampel dengan cara concesecutive sampling menggunakan rumus besar sampel yaitu di dapat sebanyak 40 responden. Pengumpulan data menggunakan lembar kuesioner. Data yang telah dikumpulkan, diolah dan dianalisis dengan menggunakan komputer program Microsoft excel dan program statistik (SPSS) versi 22.0. Hasil analisis univariat dengan mencari distribusi frekuensi dan analisis bivariat dengan uji Alternatif Fisher's Exact Test $(p<0,05)$ untuk mengetahui hubungan antar variabel. Berdasarkan hasil uji statistik terdapat hubungan antara dukungan keluarga $(\mathrm{p}=0,003,<\alpha=0,05)$, Ha diterima. Ada hubungan yang signifikan antara dukungan keluarga dengan kepatuhan ODHA menjalani pengobatan antiretroviral (ARV) di Klinik VCT Puskesmas Jumpandang Baru Kota Makassar. Kesimpulan ada hubungan dukungan keluarga dengan kepatuhan ODHA menjalani pengobatan antiretroviral (ARV) di Klinik VCT Puskesmas Jumpandang Baru Kota Makassar.
\end{abstract}

Kata Kunci : Dukungan Keluarga, Kepatuhan Terapi, ODHA. 


\section{Pendahuluan}

HIV singkatan dari Human Immunodeficiency Virus yaitu sejenis virus yang menyerang sistem kekebalan tubuh manusia. AIDS singkatan dari Acquired Immuno Deficiency Syndrom, yaitu kumpulan gejala penyakit (sindrom) yang didapat akibat turunnya kekebalan tubuh yang disebabkan oleh HIV (Ardhiyanti, Yulrina dkk, 2015).

Menurut World Health Organization (WHO) pada tahun 2014 tercatat 1,2 juta orang meninggal karena penyakit HIV. Tercatat 36,9 juta orang yang hidup dengan HIV pada akhir 2014 dengan 2,0 juta orang menjadi baru terinfeksi HIV pada tahun 2014. Sub-Sahara Afrika adalah wilayah yang paling terkena dampak 25,8 juta orang yang hidup dengan HIV pada tahun 2014. Wilayah Sub-Sahara Afrika menyumbang hamper 70\% dari total global infeksi HIV baru di seluruh dunia (WHO, 2014).

Penyebaran AIDS di Indonesia berada pada urutan ketiga yang merupakan tercepat di dunia, dilaporkan sampai dengan September 2014, jumlah kumulatif HIV di Indonesia yang dilaporkan sebanyak 150.296 orang dan AIDS 55.799 orang. Berdasarkan jenis kelamin, penderita HIV/AIDS meliputi laki-laki sebanyak 30.001 orang (\%), perempuan sebanyak 16.149 orang (\%), dan yang tidak diketahui sebanyak 9.649 (\%). Berdasarkan faktor risiko penularan HIV tertinggi adalah hubungan seks tidak aman pada heteroseksual (46,2 persen) penggunaan jarum suntik tidak steril pada Penasun (3,4 persen), dan LSL (Lelaki sesama Lelaki) (24,4 persen). Berdasarkan kelompok umur, persentase yang tertinggi pada usia 20-29 tahun (32,2 persen), usia 30-39 tahun (29,1 persen), 40-49 tahun (11,4 persen), 50-59 tahun (3,7 persen) (Diakses tgl 12 oktober 2016, Kementrian Kesehatan RI, 2014).

Data dari Komisi Penanggulangan AIDS (KPA) Kota Makassar, jumlah penderita HIV dan AIDS untuk Provinsi Sulawesi Selatan sampai dengan Juni 2013 sebanyak 6.748 kasus dengan jumlah HIV sebanyak 4482 kasus dan AIDS sebanyak 2.266 kasus, sedangkan Kota Makassar sebanyak 5.527 kasus dengan jumlah HIV sebanyak 3.854 kasus dan AIDS sebanyak 1.673 kasus (KPA AIDS Sulsel, 2013).

Prevalensi HIV/AIDS di Kota Makassar meningkat dari tahun ke tahun. Pada tahun 2013 prevalensi HIV/AIDS di Kota Makassar sebesar 0,84\% meningkat dari tahun 2012 yaitu 0,54\%. Tahun 2011 prevalensi HIV/AIDS yaitu 0,70\% meningkat dari tahun 2010 yaitu 0,49\%. Kegiatan yang dilaksanakan selama tahun 2013 berkaitan dengan penanggulangan HIV/AIDS antara lain pencegahan HIV/AIDS termasuk promosi kesehatan, monitoring dan evaluasi program HIV/AIDS dan juga pembiayaan untuk Komisi Penanggulangan AIDS (KPA) Kota Makassar. Selain itu khusus untuk penanggulangan HIV/AIDS juga telah disediakan 4 (empat) Puskesmas Percontohan yaitu Puskesmas Kassi-Kassi, Jumpandang Baru, Jongaya dan Makkasau yang merupakan 4 dari 24 unit pelayanan kesehatan yang ada di Indonesia yang siap memberikan pelayanan dan rujukan bagi penderita HIV/AIDS dan penyalahgunaan Narkoba (NAPZA) (Profil Kesehatan Kota Makassar, 2013).

Pengobatan Antiretroviral merupakan terapi yang dijalankan ODHA dengan mengkomsumsi obat seumur hidupnya dengan tujuan untuk menekan replikasi HIV dalam darah dan menurunkan kasus kematian akibat AIDS. Untuk dapat menekan replikasi virus secara maksimal setidaknya 90-95\% dari semua dosis tidak boleh terlupakan (Latif, 2014).

Berdasarkan laporan Dinkes Kesehatan Provinsi Sulawesi Selatan, 2016. Jumlah kumulatif kasus HIV dan AIDS tahun 2012 berjumlah 983 dimana 869 atau 88,4\% pasien mendapat pengobatan ARV dari 822 orang dinilai kepatuhannya, 763 orang atau 92,8\% memiliki kepatuhan diatas 95\% dan 59 atau 7,1\% orang dengan tingkat kepatuhan dibawah 95\%. Pada tahun 2013, HIV dan AIDS mencapai 1.330 kasus. Pasien HIV dengan pengobatan ARV berjumlah 1.048 orang, terdiri dari 985 orang atau 93,9\% orang dengan tingkat kepatuhan diatas $95 \%$ dan kepatuhan dibawah $95 \%$ berjumlah 63 atau 6,01\% orang.

Salah satu puskesmas yang berada di lingkup Dinkes Kota Makassar yang memberikan pelayanan dengan ODHA yaitu Puskesmas Jumpandang Baru di Kota Makassar yang sejak tahun 2006 sampai 2015 memberikan pelayanan dan rujukan bagi penderita HIV/AIDS dan penyalahgunaan Narkoba. Beberapa kelompok beresiko melakukan tes HIV di puskesmas Jumpandang Baru di antaranya wanita pekerja seksual, waria, gay, pengguna jarum suntik, kelompok resiko tinggi, pelanggan pekerja seks, dan lain-lain.Jumlah penderita dari tahun ke tahun semakin meningkat. Puskesmas Jumpandang Baru merupakan Puskesmas yang memiliki pasien HIV/AIDS terbanyak di seluruh Puskesmas di Indonesia yang melayani terapi ARV sejak tahun 2006 sampai sekarang dengan jumlah penderita sekitar 631 penderita yang terdaftar, dengan penderita yang aktif mengakses ARV 313 orang. Dari data tersebut pasien yang mengakses ARV pada bulan Juni 2016 adalah sebanyak 313 orang yang terdiri dari 230 orang laki-laki dan 83 orang perempuan. Untuk tingkat kepatuhan, jumlah pasien yang dinilai patuh adalah sebanyak 313 orang dengan derajat kepatuhan $>95 \%(<3$ dosis tidak diminum dalam 30 hari) sebanyak 256 orang dan $<80 \%$ (> 12 dosis tidak diminum dalam 30 hari) sebanyak 11 orang, dan selebihnya adalah pasien HIV/AIDS yang dinilai tidak patuh terhadap pengobatan ARV yaitu sebanyak 8 orang (Profil Puskesmas Jumpandang Baru, 2016).

Untuk meningkatkan derajat kesehatan pada penderita ODHA di perlukan adanya kepatuhan minum obat ARV. Hal ini senada dengan penelitian dari Ayalu et al (2012) dalam Latif (2014) mengungkapkan bahwa salah satu faktor yang mempengaruhi kepatuhan pengobatan Antiretroviral (ARV) adalah Faktor lingkungan atau 
sosial yang terdiri dari stigma dan diskriminasi, kelompok pemberi obat, dukungan sosial seperti dukungan dari keluarga, teman, maupun petugas kesehatan.

Kepatuhan terapi dan support system lainnya mempunyai peran besar dalam meningkatkan kualitas hidup pasien dengan HIV/AIDS, menurunkan angka kematian dan kesakitan, serta meningkatkan harapan masyarakat (Kementerian Kesehatan RI, 2014).

Berdasarkan uraian tersebut maka peneliti merasa tertarik melakukan penelitian dengan judul "Hubungan dukungan keluarga dengan kepatuhan ODHA yang menjalani terapi pengobatan antiretroviral virus (ARV) Di Klinik VCT Puskesmas Jumpandang Baru Kota Makassar”.

\section{Metode}

Penelitian ini menggunakan penelitian survey analitik dengan pendekatan cross sectional study ialah study yang mencakup semua jenis penelitian yang pengukuran variabel-variabelnya dilakukan hanya satu kali. Cross sectional adalah suatu penelitian dimana faktor resiko/ penyebab dan efeknya diambil pada saat yang bersamaan. Artinya, tiap subyek penelitian hanya diobservasi sekali saja dan pengukuran dilakukan terhadap status karakter atau variabel subjek pada saat pemeriksaan bertujuan untuk melihat faktor-faktor yang berhubungan dengan kepatuhan ODHA yang menjalani terapi pengobatan antiretrovinal virus (ARV) Di Klinik VCT Puskesmas Jumpandang Baru Kota Makassar. Penelitian ini dilaksanakan penelitian ini adalah di Klinik VCT Puskesmas Jumpandang Baru Kota Makassar pada tanggal 5 desember 2016 - 5 januari 2017. Populasi dalam penelitian ini adalah seluruh pasien HIV/AIDS yang aktif menjalani pengobatan terapi ARV di Klinik VCT Puskesmas Jumpandang Baru Kota Makassar dengan jumlah populasi 313 orang. dengan jumlah sampel sebanyak 40 responden. Adapun kriteria dari sampel adalah sebagai berikut :

1. Kriteria inklusi pada penelitian ini adalah:

a. Pasien HIV/AIDS yang datang berkunjung untuk mendapatkan terapi ARV ke Puskesmas Jumpandang Baru

b. Bersedia menjadi responden

2. Kriteria eksklusi pada penelitian ini adalah:

a. Pasien yang menderita HIV/AIDS yang menolak menjadi responden

b. Pasien HIV/AIDS dengan infeksi opportunistic

c. Pasien HIV/AIDS yang menjalani program ARV $<6$ bulan

Pengumpulan data

1. Memeriksa data (editing)

Editing adalah memeriksa data hasil pengumpulan data.

2. Memberi kode (coding)

Menyederhanakan data agar supaya pada saat pengolahan dapat dilakukan dengan mudah.

3. Pemindahan data

Memindahkan data ke dalam suatu media yang mudah ditangani untuk pengolahan data selanjutnya.

4. Tabulasi data

Menyusun dan mengorganisir data sedemikian rupa, sehingga akan dapat dengan mudah dapat diolah.

Analisa data

1. Analisis univariat

Tekhnik ini dilakukan terhadap setiap variabel hasil dari penelitian. Hasil dari analisis ini berupa distribusi frekuensi, tendensi sentral, ukuran penyebaran maupun presentase dari setiap variabel.

2. Analisis bivariat

Model analisis ini digunakan untuk melihat apakah ada hubungan antar variabel.

\section{Hasil}

1. Analisis univariat

a. Jenis Kelamin

Tabel 1. Distribusi karakteristik responden berdasarkan jenis kelamin di klinik VCT puskesmas jumpandang baru kota makassar

\begin{tabular}{ccc}
\hline Jenis Kelamin & n & \% \\
\hline Laki-laki & 31 & 77,5 \\
Perempuan & 9 & 22,5 \\
\hline Jumlah & 40 & 100 \\
\hline
\end{tabular}


Dari tabel 1 menunjukkan dari 40 responden lebih banyak responden berjenis kelamin, jumlah terbanyak adalah laki-laki yaitu sebanyak 31 orang $(77,5 \%)$, sedangkan perempuan sebanyak 9 orang $(22,5 \%)$.

b. Umur

Tabel 2. Distribusi karakteristik responden berdasarkan umur di klinik VCT puskesmas jumpandang baru kota makassar

\begin{tabular}{ccc}
\hline Umur (Tahun) & $\mathbf{n}$ & $\boldsymbol{\%}$ \\
\hline $17-25$ & 7 & 17,5 \\
$26-35$ & 16 & 40 \\
$36-45$ & 14 & 35 \\
$46-55$ & 3 & 7,5 \\
\hline Jumlah & 40 & 100 \\
\hline
\end{tabular}

Dari tabel 2 menunjukkan umur responden terbanyak adalah 26-35 tahun yaitu sebanyak 16 orang (40\%), 36-45 tahun sebanyak 14 orang (35\%), 17-25 tahun sebanyak 7 orang (17,5\%), dan 46-55 tahun sebanyak 3 orang $(7,5 \%)$.

c. Pendidikan

Tabel 3. Distribusi karakteristik responden berdasarkan pendidikan di klinik VCT puskesmas jumpandang baru kota makassar

\begin{tabular}{ccc}
\hline Pendidikan & n & \% \\
\hline Tidak Sekolah & 2 & 5 \\
SD/Sederajat & 12 & 30 \\
SMP/Sederajat & 11 & 27,5 \\
SMA/Sederajat & 13 & 32,5 \\
Perguruan Tinggi & 2 & 5 \\
\hline Jumlah & 40 & 100 \\
\hline
\end{tabular}

Dari tabel 3 menunjukkan bahwa Pendidikan responden terbanyak adalah belatar belakang pendidikan SMA/Sederajat sebanyak 13 orang (32,5\%), SD/Sederajat sebanyak 12 orang (30\%), SMP/sederajat sebanyak 11 orang (27,5\%), terendah Perguruan Tinggi sebanyak 2 orang (5\%), dan responden yang berlatar belakang pendidikan tidak sekolah sebanyak 2 orang (5\%).

d. Status Perkawinan

Tabel 4. Distribusi karakteristik responden berdasarkan status perkawinan di klinik VCT puskesmas jumpandang baru kota makassar

\begin{tabular}{ccc}
\hline Status Perkawinan & n & \% \\
\hline Menikah & 20 & 40 \\
Belum Menikah & 12 & 30 \\
Duda/Janda & 8 & 20 \\
\hline Jumlah & 40 & 100 \\
\hline
\end{tabular}

Dari tabel 4 menunjukkan bahwa status perkawinan yang tinggi yaitu menikah sebanyak 20 orang (50\%), belum menikah sebanyak 12 orang (30\%), dan status perkawinan yang terendah yaitu sebanyak 8 orang $(20 \%)$.

e. Stadium Penyakit

Tabel 5. Distribusi karakteristik responden berdasarkan stadium penyakit di klinik VCT puskesmas jumpandang baru kota makassar

\begin{tabular}{ccc}
\hline Status Perkawinan & n & \% \\
\hline I & 15 & 37,5 \\
II & 25 & 62,5 \\
III & 0 & 0 \\
\hline Jumlah & 40 & 100 \\
\hline
\end{tabular}

Dari tabel 5 menunjukkan bahwa stadium penyakit yang diderita pada responden yaitu simptomatik (stadium II) yang tertinggi sebanyak 25 orang $(62,5 \%)$, belum menikah sebanyak 12 orang 
(30\%), sedangkan yang terendah stadium penyakit yang diderita pada responden yaitu asimptomatik (stadium I) sebanyak 15 orang $(37,5 \%)$.

f. Cara Penularan

Tabel 6. Distribusi karakteristik responden berdasarkan cara penularan di klinik VCT puskesmas jumpandang baru kota makassar

\begin{tabular}{ccc}
\hline Cara Penularan & n & \% \\
\hline Seks & 18 & 45 \\
Suntik & 22 & 55 \\
\hline Jumlah & 40 & 100 \\
\hline
\end{tabular}

Dari tabel 6 menunjukkan bahwa cara penularan yang diderita pada responden yaitu suntik yang tertinggi sebanyak 22 orang (55\%), sedangkan yang terendah penularan seks sebanyak 18 responden $(45 \%)$.

g. Lama Terapi

Tabel 7. Distribusi karakteristik responden berdasarkan lama terapi di klinik VCT puskesmas jumpandang baru kota makassar

\begin{tabular}{ccc}
\hline Lama Terapi & n & \% \\
\hline 5-11 Bulan & 3 & 7,5 \\
1-5 Tahun & 21 & 52,5 \\
6-10 Tahun & 11 & 27,5 \\
11-15 Tahun & 5 & 12,5 \\
\hline Jumlah & 40 & 100 \\
\hline
\end{tabular}

Dari tabel 7 menunjukkan bahwa lama terapi pada responden yaitu 1-5 tahun yang tertinggi sebanyak 21 orang (52,5\%), lama terapi 6-10 tahun sebanyak 11 responden (27,5\%), lama terapi 11-15 sebanyak 5 responden (12,5\%), dan yang terendah lama terapi 5-11 bulan sebanyak 3 responden (7,5\%).

h. Dukungan Keluarga

Tabel 8. Distribusi karakteristik responden berdasarkan dukungan keluarga di klinik VCT puskesmas jumpandang baru kota makassar

\begin{tabular}{ccc}
\hline Dukungan Keluarga & n & \% \\
\hline Mendukung & 22 & 55 \\
Tidak Mendukung & 18 & 45 \\
\hline Jumlah & 40 & 100 \\
\hline
\end{tabular}

Dari tabel 8 menunjukkan bahwa responden yang memiliki dukungan keluarga yang tertinggi mendukung sebanyak 22 responden (55\%), sedangkan yang terendah tidak mendukung sebanyak 18 responden $(45 \%)$.

i. Perubahan Kadar CD4 Pasien

Tabel 9. Distribusi karakteristik responden berdasarkan perubahan kadar cd4 pasien di klinik VCT puskesmas jumpandang baru kota makassar

\begin{tabular}{ccc}
\hline Perubahan Kadar CD4 Pasien & n & \% \\
\hline Meningkat & 30 & 75 \\
Menurun & 10 & 25 \\
\hline Jumlah & 40 & 100 \\
\hline
\end{tabular}

Dari tabel 9 menunjukkan bahwa kategori perubahan kadar CD4 ODHA yang tertinggi sebanyak 35 orang $(75 \%)$, sedangkan yang terendah sebanyak 10 orang $(25 \%)$. 
2. Analisis Bivariat

Tabel 10. Hubungan dukungan keluarga dengan kepatuhan odha yang menjalani pengobatan arv di klinik vet jumpandang baru kota makassar

\begin{tabular}{|c|c|c|c|c|c|c|c|}
\hline \multirow{3}{*}{$\begin{array}{l}\text { Dukungan } \\
\text { Keluarga }\end{array}$} & \multicolumn{4}{|c|}{ Kepatuhan Berobat ARV } & \multirow{2}{*}{\multicolumn{2}{|c|}{ Jumlah }} & \multirow{3}{*}{$\mathbf{P}$} \\
\hline & \multicolumn{2}{|c|}{ Tidak Patuh } & \multicolumn{2}{|c|}{ Patuh } & & & \\
\hline & $\mathbf{n}$ & $\%$ & $\mathbf{n}$ & $\%$ & $\mathbf{n}$ & $\%$ & \\
\hline Mendukung & 1 & 2,5 & 20 & 50 & 21 & 52,5 & \multirow{3}{*}{0,003} \\
\hline Tidak Mendukung & 9 & 22,5 & 10 & 25 & 19 & 47,5 & \\
\hline Jumlah & 10 & 25 & 30 & 75 & 40 & 100 & \\
\hline
\end{tabular}

Dari tabel 10 menunjukkan dari 40 responden, untuk kategori yang mendapat dukungan keluarga dan patuh menjalani pengobatan ARV sebanyak 20 orang (50\%) sedangkan yang mendapat dukungan keluarga dan tidak patuh menjalani pengobatan ARV sebanyak 1 orang (2,5\%). Untuk kategori yang tidak mendapat dukungan keluarga tetapi patuh menjalani pengobatan ARV sebanyak 10 orang (25\%), sedangkan yang tidak mendapat dukungan keluarga dan tidak patuh menjalani pengobatan ARV sebanyak 9 responden $(22,5 \%)$.

Berdasarkan analisis statistik dengan menggunakan uji “alternative Fisher's Exact Test” didapatkan nilai $\mathrm{p}=0,003$ yang berarti lebih kecil dari nilai $\alpha=0,05$. Maka Ho ditolak sedangkan Ha diterima. Maka dalam penelitian ini dapat disimpulkan bahwa ada hubungan antara dukungan keluarga dengan kepatuhan penobatan ARV di Klinik VCT Jumpandang Baru Kota Makassar.

\section{Pembahasan}

Dukungan sosial dari keluarga, teman dan tenaga kesehatan memberikan pengaruh penting, mereka berpotensi untuk dua kali lebih patuh terhadap pengobatan dibanding pasien HIV yang tidak mendapat dukungan positif dari keluarga mereka.

Berdasarkan hasil analisis statistik dengan menggunakan uji "alternative Fisher's Exact test" didapatkan nilai $p=0,003$ yang berarti lebih kecil dari nilai $\alpha=0,05$. Maka Ho ditolak sedangkan Ha diterima. Maka dalam penelitian ini dapat disimpulkan bahwa ada hubungan antara dukungan keluarga dengan kepatuhan penobatan ARV di Klinik VCT Jumpandang Baru Kota Makassar.

Hal ini sejalan dengan penelitian yang dilakukan Sugiharti pada tahun 2012 mengungkapkan bahwa dukungan dari keluarga (orangtua, suami, dan saudara) dalam penelitian ini adalah memberikan motivasi kepada ODHA dan meningkatkan kepatuhan untuk minum obat. Bagi ODHA yang sudah diketahui statusnya oleh keluarga dan keluarganya dapat menerima kondisi mereka, maka faktor keluarga biasanya menjadi pendukung utama. Biasanya orang tua, suami/istri, anak menjadi orang-orang terdekat yang mengingatkan unuk minum obat. Keluarga dalam hal ini bisa berfungsi menjadi Pengawas Minum Obat (PMO) bagi ODHA. Akan tetapi ada kondisi keluarga yang justru menghambat kepatuhan misalnya takut diketahui pasangannya sebagai ODHA sehingga menjadi berhenti minum obat.

Hasil penelitian berbanding terbalik dengan penelitian yang dilakukan oleh Saputro pada tahun 2012 menunjukkan bahwa tidak terdapat hubungan antara dukungan keluarga dengan kepatuhan terapi ARV. Menurut pengamat peneliti, responden tidak mau memberitahukan bahwa responden tersebut mengidap HIV karena merasa takut dan malu sehingga responden menutupi statusnya, namun banyak responden yang patuh selain dukungan keluarga, pemaberian informasi yang cukup membuat responden memahami pentingnya pengambilan ARV yang teratur. Ini terlihat dari banyaknya responden yang patuh persentase kepatuhan $>95 \%$, sehingga membuat pasien walaupun tidak didukung oleh keluarga akan menjadi patuh.

Peneliti berpendapat bahwa dukungan keluarga sangat berpengaruhi dengan kepatuhan pengobatan, karena adanya dorongan dari keluarga yang mau menerima statusnya penyakit yang dialami serta mendukung keberhasilan pengobatannya. Selain itu pemberian informasi yang cukup, memiliki motivasi dan keyakinan, serta pemahaman pentingnya mengkomsumsi ARV yang teratur.

Jadi, Kepatuhan ARV bukan hanya dari dukungan keluarga bahkan dari faktor internal karena sebagian responden merasa malu, sehingga responden menutupi status penyakitnya dengan alasan ingin sehat, bertahan hidup dan pernah merasakan sakit dan kondisi fisik menurun hingga dirawat di RS setelah putus obat ARV.

\section{Kesimpulan}

Hasil penelitian yang dilakukan di Klinik VCT Puskesmas Jumpandang Baru Kota Makassar mengenai hubungan dukungan keluarga dengan kepatuhan ODHA yang menjalani pengobatan ARV di Klinik VCT Puskesmas Jumpandang Baru Kota Makassar yang dilaksanakan pada tanggal 5 desember 2016 sampai dengan 5 Januari 2017, dengan jenis penelitian survey analitik, dengan jumlah sampel 40 orang, maka dapat 
disimpulkan bahwa: Ada hubungan antara dukungan keluarga dengan kepatuhan ODHA yang menjalani pengobatan antiretroviral (ARV) di Klinik VCT Puskesmas Jumpandang Baru Kota Makassar.

\section{Saran}

Bagi Klinik VCT Puskesmas Jumpandang Baru Kota Makassar agar tetap dipertahankan sistem pelayanan bagi pasien ODHA seperti pemberian konseling, pemberian obat ARV secara gratis.

Bagi petugas VCT diharapkan agar terus meningkatkan pengetahuan akan terapi ARV baik ODHA yang sudah lama menjalani terapi, dengan demikian diharapkan dari pengetahuan yang baik akan muncul persepsi yang baik.

Bagi ODHA diharapkan agar lebih percaya diri dan semangat dalam menjalani pengobatan sehingga diharapkan untuk tetap patuh serta memanfaatkan akses layanan yang telah tersedia dan melakukan banyak kegiatan yang positif untuk membantu sesame.

Bagi keluarga pendamping responden dalam menjalani pengobatan diharapkan agar aktif mengikuti penyuluhan dan seminar tentang kesehatan yang berkaitan dengan penyakit HIV, sehingga keluarga dapat mengaplikasikan ilmu dan bisa memberikan perhatian penuh, agar mereka tidak merasa diskriminasikan. Sehingga mereka tetap nyaman dan terus patuh menjalani pengobatan.

Diharapkan kepada peneliti selanjutnya untuk melakukan penelitian dengan melihat kepatuhan pengobatan ARV pasien secara berkala agar dapat dievaluasi secara berkesinambungan

\section{Referensi}

Ardhiyanti, Yulrina dkk. (2015). Buku Ajar AIDS Pada Asuhan Kebidanan. Yogyakarta: CV Budi Utama.

Depkes RI. (2007). Pedoman Nasional Tatalaksana Terapi Antiretroviral.Paduan Tatalakasan Klinis Infeksi HIV pada Orang Dewasa dan Remaja. Edisi Kedua. Kementrian Kesehatan RI: Jakarta.diakses dari website; http://spiritia.or.id/dokumen/pedoman-art2007.pdf Depkes RI. (2011). Pedoman Nasional Tatalakasan Klinis Infeksi HIV pada Orang Dewasa. Kementrian Kesehatan RI: Indonesia. Diakses dari website : $\underline{\text { http://www.spiritia.or.id/Dok/pedomanart2.pdf }}$

Dinkes Kota Makassar. (2013). Profil Kesehatan Kota Makassar 2013. Diakses dari website http://dinkeskotamakassar.net/download/718Gabung\%20profil\%202013.pdf.

Hidayat, A A A. (2014). Metode Penelitian Keperawatan dan Teknik Analisa Data. Jakarta: Salemba Medika.

Kemenkes RI. (2014). Profil Kesehatan Indonesia 2014.Diakses dari website http://www.depkes.go.id/resources/download/pusdatin/profil-kesehatan-indonesia/profil-kesehatanindonesia-2014.pdf.

Komisi Penanggulangan AIDS Kota Makassar. (2013). Laporan Kementerian Kesehatan.http://www.aidsindonesia.or.id/list/7/Laporan-Menkes

Latif, Fachri, dkk. (2014).Efek Samping Obat Terhadap Kepatuhan Pengobatan Antiretroviral Orang Dengan HIV/AIDS.Jurnal Kesehatan Masyarakat Nasional Vol. 9, No. 2, November 2014. Website: http://download.portalgaruda.org/article.php?article=364792\&val=7113\&title=Efek\%20Samping\% 20Obat\%20terhadap\%20Kepatuhan\%20Pengobatan\%20Antiretroviral\%20Orang\%20dengan\%20H IV/AIDS

Susanto, Tantu. (2012). Buku Ajar Keperawatan Keluarga Aplikasi Teori Pada Praktek Asuhan Keperawatan Keluarga.Jakarta: CV.Trans Info Media. 